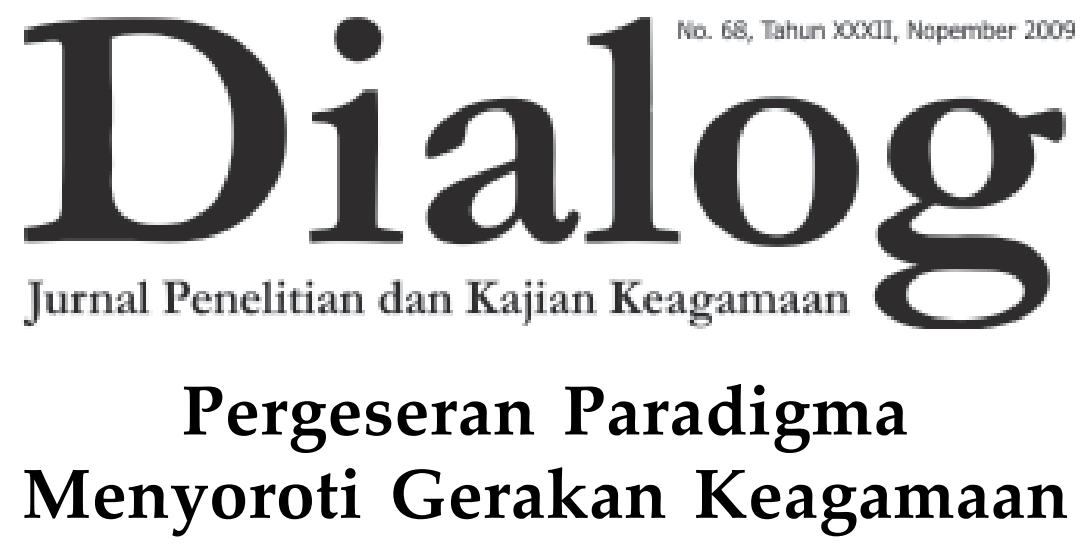




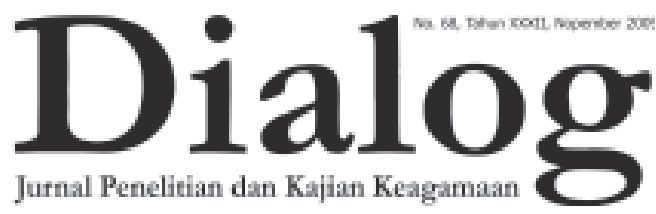

Pemi mpin Umum:

Prof. Dr. H. M. Atho Mudzhar, MA

Redaktur Ahli:

Prof. Dr. H. Nasaruddin Umar, MA

Prof. Dr. H. Komarudin Hidayat, MA

Pemimpin Redaksi / Penanggung J awab

Drs. H. Syamsuddin

Wakil Pemi mpin Redaksi

H. Fanani Suprianto, SH., MM

Sekretaris Redaksi

M. Rosyid Fauzi, S.Si.

Dewan Redaksı

Prof. Dr. H. Abdurrahman Mas'ud Drs. Amin Haedari

Prof. Dr. H. Maidir Harun

Drs. H. Mohammad Shohib, MA

Drs. H. Asmu'i, SH, MM

Chamdi Pamudji, SH., MM

Redaktur Eksekutif

M. Nasir, S.Th.I.

Redaktur Pelaksana

Moh. Rosyid Fauzi, S.Si

M. Nasir, S.Th.I

M. Adlin Sila, M.A

Abbas Jauhari, M.Ag

Administrasi

Drs. Dedy Curipno

Sutidjah

Desriyanti Nasution, S.IPI

Drs. H. Sahlani

Alamat Redaksi

Gedung Bayt Alquran Museum Istiqlal Komplek Taman Mini Indonesia Indah

Telp. (021) 87791444-87794982

Website:

www. balitbangdiklat.depag.go.id

Email:

info@depag.web.id

\section{Pergeseran Paradigma Menyoroti Gerakan Keagamaan}

Fenomena munculnya berbagai aliran keagamaan di Indonesia beberapa tahun terakhir menunjukan kecenderungan positif dalam kebebasan beragama. Namun sayangnya kebebasan menampilkan ekspresi keberagamaan tersebut kerapkali melampaui dari apa yang semestinya. Hal tersebut dapat kita lihat dengan munculnya gerakan keagamaan yang mengusung berbagai macam ajaran, ritual keagamaan yang aneh bahkan cenderung mengancam serta menodai kesucian aqidah, ibadah, ritual, dan pendirian mayoritas ummat yang sudah mapan. Sejak tahun 1989, setidaknya telah ada beberapa aliran keagamaan diberikan label haram oleh MUI (Majelis Ulama Indonesia), diantara aliran yang dianggap menyesatkan itu antara lain: Islam Jama'ah, Ahmadiyah, Ingkar Sunnah, Qur'an Suci, Sholat Dua Bahasa, Lia Eden dan al-Qiyadah al-Islamiyah.

Fenomena ini ditenggarai oleh sebagian pihak sebagai akibat dari kegagalan dakwah. Para da'i dianggap tidak mampu mentransformasikan nilainilai ajaran Islam secara kaffah 
(komprehensif) kepada ummat, dakwah selama ini sering bersifat eksklusif, menghakimi dan memprovokasi. Aktifitas dakwah hanya menampilkan Islam dari aspek langit atau 'ubudiyah (habluminallah) bukan aspek bumi dimana kehidupan sosial (habluminannas) bergulir, sehingga wajar berbagai permasalahan sosial yang dialami ummat tidak tersentuh. Fakta ini menyebabkan ummat mencari solusi lain atas permasalahan sosial yang mereka alami dengan cara "selingkuh" yaitu menganut sekte atau aliran baru dalam sebuah agama yang menawarkan solusi instan, namun cenderung "menyesatkan".

Para da'i, tokoh masyarakat, maupun para pemegang kebijakan ke depan harus mampu merubah paradigma yang selama ini salah dan telah mengkristal di kalangan ummat. Mereka diharapkan tidak berperan sebagai juru dakwah, juru vonis, juru putus, yang hanya menyampaikan pesan bil lisan di atas mimbar saja, tapi lebih dari itu, merek dituntut menjadi -meminjam istilah Clifford Geertz- cultural broker (makelar budaya), bahkan menjadi intermediary forces (kekuatan perantara) bagi permasalahan sosial ummat dalam istilah Hiroko Horikoshi.

Dalam kajian Jurnal Dialog Edisi ini mencoba mengulas tentang Pergeseran Paradigma Menyoroti Gerakan Keagamaan yang kerapkali menghadirkan tematema aktual di tengah-tengah masyarakat. Kajian Jurnal Dialog edisi ini diawali dengan tulisan Prof. Dr. H.M.
Atho Mudzhar tentang Instrumen Internasional dan Peraturan Perundangan Indonesia tentang Kebebasan dan Perlindungan Beragama. Dilanjutkan dengan tulisan Prof. Dr. Abdurrahman Mas'ud yang mengupas tentang Menyikapi Keberadaan Aliran Sempalan.

Sukris Sarmadi, Dosen STAIN Banjarmasin menghadirkan tulisan tentang Transformasi NU dalam Masyarakat Banjar Kini PerspektifPergeseran Gerakan Keagamaan di Kalimantan Selatan. Sedangkan M. Ulinnuha Khusnan, MA melalui tulisannya mencoba memotret Paradigma Keberagamaan Kaum Santri. Nurhasanah dosen UIN Jakarta menghadirkan tulisan tentang Politik Kebijakan Islamisasi Mahathir. Kajian jurnal dialog edisi ini kian lengkap dengan hadirnya tulisan Anwar Mujahidin, MA, tentang Science And Religion (Paradigma Al-Qur'an untuk IlmuIlmu Sosial Menurut Pemikiran Kuntowijoyo).

Di samping memuat artikel ilmiah, Jurnal Dialog edisi ini juga memuat laporan hasil penelitian oleh Ridwan Bustaman, tentang Analisis Wacana Kritis : Tayangan Kekerasan dalam Sinetron Bernuansa Keagamaan. Dan juga hasil penelitian saudara Basuki tentang Pesantren, Tasawufdan Hedonisme Kultural (Studi Kasus Aktualisasi Nilai-nilai Tasawuf dalam Hidup dan Kehidupan di Pondok Pesantren Modern Gontor). Serta hasil penelitian saudari Maryam tentang Interaksi Sosial Pelaku Konversi Agama Etnik Cina.

Kajian ini diakhiri dengan telaah 
buku yang mengulas buku karya Prof. Abdurrahman, 2009 yang berjudul Menebar Rahmat bagi Sekalian Alam. Semoga kajian yang dihadirkan Jurnal Dialog edisi ini memberikan manfaat yang berarti bagi para pembaca, khususnya dalam kajian Pergeseran Paradigma Menyoroti Gerakan Keagamaan. Selamat Membaca!

Redaksi

4 Dialog No. 68, Tahun XXXII, Nopember 2009 
TOPIK

M. Atho Mudzhar

Instrumen Internasional dan Peraturan Perundangan Indonesia tentang Kebebasan dan Perlindungan Beragama - -6

Abdurrahman Mas'ud

Menyikapi Keberadaan Aliran Sempalan --16

SUKRIS SARMADI

Transformasi NU dalam Masyarakat Banjar Kini Perspektif Pergeseran Gerakan Keagamaan di Kalimantan Selatan - 25

\section{Ulinnuha KhuSNAN}

Memotret Paradigma Keberagamaan Kaum Santri —41

\section{NuRHASANAH}

Politik Kebijakan Islamisasi Mahathir —65

\section{Anwar Mujahidin}

Science And Religion (Paradigma Al-Qur'An untuk Ilmu-Ilmu Sosial Menurut Pemikiran Kuntowijoyo) -78

\section{PENELITIAN}

\section{RidWAN Bustamam}

Analisis Wacana Kritis : Tayangan Kekerasan dalam Sinetron Bernuansa Keagamaan $\longrightarrow 97$

\section{BASUKI}

Pesantren, Tasawuf dan Hedonisme Kultural (Studi Kasus Aktualisasi Nilainilai Tasawuf dalam Hidup dan Kehidupan di Pondok Pesantren Modern Gontor) -112

MARYAM

Interaksi Sosial Pelaku Konversi Agama Etnik Cina --135

\section{BOOK REVIEW}

\section{Dewi $\mathbf{N}$}

Menebar Rahmat bagi Sekalian Alam —149 


\title{
Interaksi Sosial \\ Pelaku Konversi Agama Etnik Cina
}

\author{
OLEH : MARYAM YUSUF*)
}

\begin{abstract}
The conflicts involve some parts of religius aspects or demensions like belief, rite, leadership, institution, knowladge, pratice, symbol, rationality and consequensces often occurd as the conflict-simbol at etnic. But on the orher hand there are some of Chinese at Ponorogo do conversion from their old belief to Islam. That is the phenomena will be increased to analyze based on emic prespective to comprehend the meaning of conversion. The main purpose of this research is to comprehend the meaning and motivations of conversion. The objective of this research are to analyze the phenomena of conversion proses, comprehend meaning and motivation meaning. To investigate the rationality of conversion from being Chinese. Secondly, it is to discover of converts the social and relegious behaviour of the conversion, in which the consequences of conversion to analyze and describe based on invetigation. It's social interaction between converts and moslem (Javanese) and others. By using qualitative approach, emic perspective, interviewing some identified converts, observing religius social setting and reading document information this research carried out at Ponorogo district, this article discovered that the oneness of God Rationality or Tawhid Rationality. The converts in this case make comparation with their belief before Islam. They know about syari'at Islam and effort to do as well as possible
\end{abstract}

\section{KEYWORD :}

Religius Conversion, Etnic Studies, Rationality

\section{Pendahuluan}

\section{A. Latar Belakang Masalah}

Para ahli sosiologi berpendapat bahwa yang menyebabkan terjadinya konversi agama adalah pengaruh sosial. Ada beberapa faktor sosial yang mendorong terjadinya konversi. Faktorfaktor tersebut antara lain hubungan

*) Dosen STAIN Ponorogo antarpribadi, baik bersifat keagamaan maupun non-agama, kebiasaan yang rutin, anjuran dan propaganda pemimpin keagamaan, kumpulan yang berdasarkan hobi, dan pengaruh kekuasaan pemimpin (Ramayulis, 2002: 64).

Konversi agama yang terjadi pada etnis Cina akan lebih mendapat sorotan terutama dari pemeluk agama baru. Yaitu orang Cina yang pindah agama 
dari non Islam masuk Islam menjadi sorotan dari pemeluk agama Islam. Hal ini disebabkan karena adanya pemikiran perbedaan ras terutama terhadap etnis Cina. Ada yang menyangka dari kalangan Muslim bahwa orang Cina masuk Islam ingin selamat, ada juga yang masih mencurigai eksistensi etnis Cina, ada yang selalu ingin membaur. Namun karena adanya kecurigaan tersebut akhirnya mengalami hambatan. Tindakan konversi agama yang dilakukan oleh etnis Cina sama dengan proses konversi pada umumnya yaitu selalu ada peristiwa atau kondisi yang menyebabkan sehingga terjadi tindakan tersebut, bukan hanya mengejar atau mencapai tujuan tertentu saja. Dengan adanya sorotan dan kecenderungan dari pihak orang Islam, yang bukan Cina (etnis Jawa) terhadap Cina Islam sehingga menimbulkan hubungan yang kurang harmonis. Hal ini merupakan sesuatu yang perlu digali, mengapa terjadi seperti itu.

Penelitian ini berfokus pada konversi agama kelompok masyarakat Cina menjadi muslim. Istilah konversi agama dalam hubungannya dengan proses perpindahan dari suatu agama ke agama lain yaitu dari agama lama ke agama baru (Islam). Disamping perilaku beragama mereka setelah menjadi muslim, interaksi sosial Cina muslim, baik sesama muslim dan pemeluk agama lainnya dari kelompok etnis Cina juga menjadi perhatian dalam penelitian ini. Penelitian ini dilakukan di kota Ponorogo karena masyarakat Cina muslim telah terbentuk lama di kota tersebut dan telah berintegrasi dan berinteraksi cukup lama, namun masih ada masalah atau ketidakharmonisan, kecurigaan dan ketidakpercayaan.
B. Rumusan Permasalahan

1. Bagaimana perilaku sosial keagamaan etnis cina setelah menjadi muslim ?

2. Bagaimana interaksi sosial antara Cina muslim dengan sesama muslim, baik dari Cina maupun Jawa dan sesama etnis Cina yang beragama lain?

\section{Tujuan dan Kontribusi \\ Penelitian}

Secara umum, penelitian ini bertujuan untuk memahami proses konversi agama dan interaksi sosial etnis Cina muslim dengan masyarakat muslim pada umumnya dan dengan masyarakat etnis Cina lainnya yang memeluk agama lain. Secara rinci, tujuan tersebut bisa dijabarkan sebagai berikut:

1. Untuk mendeskripsikan, menganalisis dan menginterpretasikan pola perilaku sosial keagamaan mereka setelah menjadi muslim.

2. Untuk mendeskripsikan, menganalisis dan menginterpretasikan pola interaksi sosial antara Cina muslim dengan sesama muslim baik dari etnis Cina maupun etnis Jawa dan sesama etnis Cina yang beragama lain.

\section{Tinjauan Pustaka \\ A TeOri yang Di gunaKan \\ 1. Symbolic INTERACTIONISM (TeORI INTERAKSIONISME SIMBOLIK)}

Herbert Blumer, yang merupakan arsitek utama teori Interaksionisme Simbolik menyatakan bahwa istilah "interaksi simbolik" menunjuk pada sifat khusus dan khas interaksi yang berlangsung antarmanusia. Kekhususan itu terutama dalam fakta bahwa manusia menginterprestasikan atau mendefinisikan tindakan satu sama lain dan tidak semata-mata bereaksi atas 
tindakan satu sama lain. Jadi interaksi manusia dimediasi oleh penggunaan simbol-simbol, oleh interprestasi, atau oleh penetapan makna dari tindakan orang lain.

Pendekatan interkasionisme simbolik memberikan banyak penekanan pada individu yang aktif dan kreatif daripada pendekatan-pendekatan teoritis lainnya. Pendekatan interaksionisme simbolik berkembang dari sebuah perhatian ke arah bahasa; namun Mead mengembangkan hal itu dalam arah yang berbeda dan cukup unik. Pendekatan interaksionisme simbolik menganggap bahwa segala sesuatu tersebut adalah virtual. Semua interaksi antarindividu manusia melibatkan suatu pertukaran simbol. Ketika kita berinteraksi dengan yang lainnya, kita secara konstan mencari "petunjuk" mengenai tipe perilaku apakah yang cocok dalam konteks itu dan mengenai bagaimana menginterprestasikan apa yang dimaksudkan oleh orang lain. Interaskionisme simbolik mengarahkan perhatian kita pada interaksi antar individu, dan bagaimana hal ini dapat dipergunakan untuk mengerti apa yang orang lain katakan dan lakukan kepada kita sebagai individu.

Berikut asumsi-asumsi interaksionisme simbolik yang dikemukakan oleh Herbert Blumer (Blumer, 1969: 2 lihat juga Poloma, 2000: 258 dan Craib, 1992:112).

a. Manusia bertindak terhadap sesuatu berdasarkan makna-makna yang ada pada sesuatu itu bagi mereka.

b. Makna tersebut berasal dari interaksi sosial, seseorang dengan orang lain.

c. Makna-makna tersebut disempurnakan di saat proses interaksi sosial berlangsung.
Makna-makna tersebut berasal dari interaksi dengan orang lain terutama dengan orang yang dianggap cukup berarti. Bagi seseorang makna dari sesuatu berasal dari cara-cara orang lain bertindak terhadapnya dalam kaitannya dengan sesuatu itu. Tindakan-tindakan yang mereka lakukan akan melahirkan batasan sesuatu bagi orang lain. Aktor memilih, memeriksa, berfikir, mengelompokkan dan mentransformasikan makna dalam hubungannya dengan situasi dimana dia ditempati dan arah tindakannya. Sebenarnya interpretasi seharusnya tidak dianggap hanya sebagai penerapan makna-makna yang telah ditetapkan, tetapi sebagai suatu proses pembentukan dimana makna dipakai dan disempurnakan sebagai instrumen bagi pengarahan dan pembentukan tindakan (Blumer, 1969: $5)$.

\section{FenOMENOLOGI}

Alfred Schutz sebagai salah seorang tokoh teori ini bertolak dari pandangan Weber pula, dia berpendirian bahwa tindakan manusia menjadi suatu hubungan sosial bila manusia memberikan arti atau makna tertentu terhadap tindakannya itu, dan manusia lain memahami pula tindakannya itu sebagai suatu yang penuh arti.

Meskipun semua tindakan bermakna dalam arti bahwa tindakan senantiasa adalah melakukan sesuatu dengan sadar, yaitu selalu terarah menuju penyelesaian sebuah tindakan yang diproyeksikan si pelaku dalam pikiran sendiri, Schutz mengikuti Hesserl dengan menyatakan bahwa proses pemahaman aktual kegiatan kita dan memberi makna padanya adalah sesuatu yang dihasilkan hanya melalui refleksi atas tingkah laku kita bila proses 
itu berlalu karena pemahaman macam itu perlu membagi-bagi arus tindakan menjadi sebuah rentetan tindakan yang terpilah-pilah dengan tujuan-tujuan yang dapat dibedakan.

Lebih lanjut menurut Schutz dalam Tom Campbell (1994: 236) ada hal yang lebih mengejutkan dalam menemukan segi-segi yang menentukan dalam kehidupan sehari-hari yang menurut Schutz tidak bisa secara memadai dimengerti ketika manusia merefleksikan dirinya sendiri saat bertindak. Ingatan tidak bisa menciptakan kembali pengalaman hidup yang masih diingat (sebuah kenyataan yang dipakai Smith untuk menjelaskan tidak adanya simpati pada kita selama kita berada di dalam emosi-emosi yang kuat yang membuat tidak stabil). Dengan merefleksikan tingkah laku kita di masa silam, kita pasti tidak bisa berhasil menangkap unsur-unsur khas dan hakikinya, persis yang terjadi waktu itu. Jadi dengan meninjau kembali dengan memberi makna kepada tingkah laku dengan memecah-mecah masa silam menjadi berbagai waktu dan saat yang terpisahpisah, tetapi dalam kenyataan apa yang dialami adalah sebuah aliran tetap penginderaan-penginderaan yang berpadu satu sama lain. Bagaimanapun dunia tindakan yang "pra fenomenal" inilah yang dianggap Schutz sebagai sesuatu yang fundamental untuk kehidupan sosial manusia dan karenanya dia berusaha menganalisisnya sebaik mungkin.

Schutz mengkhususkan perhatiannya kepada satu bentuk dari subjektifitas yang disebut antarsubjektifitas. Konsep ini menunjukan kepada dimensi pemisahan dari kesadaran umum kepada kesadaran khusus kelompok sosial yang saling berinteraksi.
Antarsubjektifitas yang memungkinkan pergaulan sosial itu terjadi, tergantung pada pengetahuan tentang peranan masing-masing yang diperoleh melalui pengalaman yang bersifat pribadi. (Ritzer, 1992:70).

Dengan teori fenomenologi, penulis berusaha mengetahui dan memahami tentang tindakan konversi agama yang dilakukan etnis Cina di Ponorogo secara subjektif yaitu yang ditujukan kepada dirinya. Dengan demikian penulis tidak menerapkan ukuran-ukuran sendiri terhadap tindakan konversi agama itu tetapi memahami tindakan itu dengan cara menemukan makna tindakan konversi agama tersebut yang sama dengan pelaku konversi agama tersebut. Untuk hal itu maka peneliti perlu melakukan metode observasi.

\section{B. Konversi Agama dalam Sudut Pandang Penelitian Terdahulu}

1. Kisah Imam al-Ghazali (w. $1111 \mathrm{M}$ ) adalah contoh konversi dalam pengertian berubah pandangan terhadap agamanya. Sebelumnya, ia hidup di tengah kemakmuran, kemegahan dan kemuliaan duniawi yang telah dicapainya. Ia kemudian berubah dengan menjalani kehidupan zuhud dan uzlah (mengasingkan diri) untuk melakukan ibadah kepada Allah (Mahmud, 2001: 40). Keadaan yang dialami Imam al-Ghazali ini merupakan konversi agama, di mana terjadi perubahan pandangan dan pendirian terhadap agama yang dianutnya. Sebelumnya, al-Ghazali berpendirian bahwa sebagai guru besar di Universitas Nizamiyah pada masa Perdana Menteri Nizam alMulk merupakan kebesaran dan kemuliaan yang dicapainya sendiri. 
Akan tetapi, pandangan ini kemudiaan dikoreksinya sendiri dan kemudian berpaling sepenuhnya menuju kehidupan sufistik dengan meninggalkan segala kemegahan dunia.

2. Studi kasus tentang proses konversi di suatu desa bernama Kuryur di India yang dilakukan oleh $\mathrm{T}$. Abdurrahman bahwa proses konversi agama di wilayah ini tidak dipengaruhi oleh adanya janji uang dan pekerjaan dari pihak luar negeri tetapi karena kesadaran akan tingginya nilai ajaran Islam. Perubahan perilaku para pemeluk agama baru ini juga menjadi titik perhatiannya. Dan ternyata para pemeluk agama baru (pelaku tindakan konversi merasa tenang dan senang jiwanya). Konversi agama telah dapat mengembangkan kerja sama di antara mereka dengan membentuk jamaah untuk mendiskusikan dan memutuskan tentang tindakan apa yang harus mereka lakukan. (Rahman, 1989: 24). Konversi agama merupakan multiaspek dan tidak semua proses konversi agama bisa disamakan. Proses konversi kepada Islam merupakan proses yang kompleks dan berlangsung lama. Proses tersebut merupakan pilihan yang sadar dan bukan merupakan hasil keputusan terhadap konflik kepercayaan yang mendadak. (Kose, 1996: 189).

3. Selanjutnya Humphreys mengemukakan empat prespektif: pertama, prespektif orang yang melakukan konversi agama, kedua, perspektif kelompok sosial tertentu (desa, suku, pusat kota dan lain-lain) yang anggotanya terlibat dalam konversi agama, ketiga, prespektif komunitas non muslim sebagai asal orang yang melakukan konversi agama, keempat, prespektif komunitas muslim yang menerima orang yang melakukan konversi agama. (Humphreys, 1991: 275). Konversi agama banyak menyangkut kejiwaan dan pengaruh lingkungan tempat seseorang berada. Para ahli ilmu jiwa berpendapat bahwa yang menjadi pendorong terjadinya konversi agama adalah faktor psikologis yang ditimbulkan oleh faktor intern dan ekstern. Faktorfaktor tersebut apabila mempengaruhi seseorang atau kelompok hingga menimbulkan tekanan batin, maka akan mendorong untuk mencari jalan keluar untuk menemukan ketenangan batin.

Perbedaan penelitian ini dengan penelitian terdahulu tentang konversi agama terletak pada pelaku konversi adalah etnis Cina yang melakukan konversi agama dari non Islam ke Islam yang belum tersentuh dalam penelitian terdahulu. Disamping itu sebagai akibat dari konversi agama yang dilakukan oleh etnis Cina menimbulkan perilaku sosial keagamaan dan interaksi sosial yang berbeda dari sebelumnya. Perilaku sosial keagamaan dan interaksi sosial sebagai akibat dari konversi agama yang dilakukan oleh etnis Cina juga belum tersentuh dalam penelitian terdahulu. Dengan demikian maka penelitian ini masih asli dan perlu dilakukan. 


\section{Metode Penelitian}

\section{A. Pendekatan Penelitian}

penelitian ini mengikuti pemikiran sosiologi interpretative dan fenomenologis sehingga digunakan metode verstehen sebagaimana yang digunakan oleh Weber, atau interpretative understanding untuk memahami fenomena yang diselidiki. Interpretasi dilakukan secara hati-hati terhadap data empiris yang dipandang sebagai hasil dari interpretasi. Dengan metode refleksi, peneliti memahami interpretasi serta pemahaman para perilaku konversi agama terhadap tindakan mereka. Dengan demikian penelitian ini bertolak dari paradigma definisi sosial.

\section{B. JENIS DATA YANG DIKUMPULKAN DALAM PENELITIAN INI MELIPUTI:}

1. Data tentang sebab-sebab mereka melakukan konversi agama. Sebabsebab itu baik yang datang dari dalam (dari dirinya sendiri) maupun yang datang dari luar (faktor sosial).

2. Data tentang perilaku sosial keagamaan pelaku konversi agama di tengah masyarakat. Data tentang perilaku pelaku konversi agama akan ditunjukan dalam hubungannya dengan nilai-nilai dari agama yang dianutnya (Islam) baik dalam konteks hubungan dengan manusia ataupun dengan Allah SWT.

3. Data yang dapat mendeskripsikan tentang interaksi sosial pelaku konversi setelah menjadi muslim dengan masyarakat sekitarnya, baik sesama Cina muslim, Cina non muslim maupun masyarakat Jawa.

\section{Perilaku $s$} Keagamaa - Orientas Kemasya - Bauran a Asimilas - Kepedul 
C. Prosedur Pengumpulan Data

1. Proses Memasuki Lokasi Penelitian (Getting In). Pada tahap ini peneliti memasuki rumah dan kantor PITI dimana ada informan yang dituju dengan membawa surat ijin formal sebagai bukti bahwa peneliti benarbanar melakukan penelitian.

2. Ketika Berada di Lokasi Penelitian (Getting Along). Pada tahap ini peneliti telah menjalin interaksi yang baik dengan subyek penelitian, mencari informasi yang lengkap dan dibutuhkan, serta menangkap makna (verstehen) dari informasi dan pengamatan yang diperoleh. Penelitian ini secara total membutuhkan waktu yang relatif lama, kurang lebih hampir 2 (dua) tahun mulai dari proposal penelitian, masa penelitian, pengolahan data hingga membuat laporan penelitian ini.

3. Logging Data yang dilakukan dengan beberapa tahapan sebagai berikut :

a. Observasi untuk mengawali peristiwa yang berupa interaksi sosial etnis Cina yang melakukan konversi agama dengan etnis Cina yang tidak melakukan konversi agama dan antara etnis Cina yang melakukan konversi agama dengan orang Islam yang bukan Cina (Jawa).

b. Wawancara (interview) yang intensif dan mendalam telah dilakukan kepada para pelaku konversi agama yaitu etnis Cina yang masuk Islam. untuk mengungkap apa arti konversi agama bagi mereka, mengapa mereka melakukan konversi agama dan untuk apa mereka melakukan tindakan tersebut. c. Dokumentasi yaitu dengan melihat dokumen-dokumen yang ada dengan peristiwa konversi agama dan kegiatan orang-orang Cina yang melakukan konversi agama seperti dokumen peng-Islaman yang ada di kantor Departemen Agama Kabupaten Ponorogo.

D. TeKnik Analisis Data

1. Open Coding; Pada tahap ini, kegiatan pengumpulan dan analisis data dan pengambilan sampel bertujuan untuk menjajaki dan menemukan sebanyak mungkin kategori yang mencerminkan pola atau macam bentuk konversi agama, macam bentuk prilaku sosial keagamaan dan variasi pola interaksi sosial antara Cina dengan para pemimpim masyarakat, ulama, pemeluk agama lain yang terjadi dalam berbagai macam setting.

2. Axial Coding; Adalah cara menggunakan "model paradigma grounded theory" yang dikembangkan sewaktu penelitian berlangsung, model paradigma tersebut dengan alur pemikiran. Pada tahap ini, kegiatan penelitian ditujukan untuk mengembangkan hipotesis dengan cara menghubungkan kategorikategori yang diperoleh dalam tahap open coding.

3. Selective Coding; Pada tahap ini, kegiatan penelitian hampir mirip dengan tahap axial coding. Perbedaannya hanyalah pada tekanan analisisnya yang lebih abstrak sesuai dengan tujuan akhir dari penelitian, yaitu membentuk kesimpulan teoritis tentang pola proses konversi agama. 
IV. Hasil Penelitian

A. Faktor Yang Mempengaruhi

Tindakan Konversi Agama

\section{FaKtor Sosiologis}

Secara sosiologis, etnis Cina, sebagaimana etnis lain yang hidup bersama dalam lingkungan tertentu, memiliki polanya tersendiri. Faktor sosiologis merujuk pada faktor lingkungan sosial dimana pelaku konversi berinteraksi dengan masyarakat sekitar. Dari data yang diperoleh, secara umum memberikan gambaran bahwa adanya kebersamaan dan toleransi yang tinggi. Untuk lebih detailnya akan faktor sosilogis yang dimaksud, dapat diketahui melalui penjabaran sebagai dibawah ini:

a. Pengaruh Hubungan Antarpribadi

Dalam sudut pandang pelaku konversi agama, tidak dapat dikesampingkan bahwa hubungan antarpribadi dalam konteks sosial merupakan salah satu faktor terjadinya konversi agama. Meskipun kadarnya tidak dominan, akan tetapi bisa jadi dalam hubungan sosial secara pribadi (face to face) dengan orang lain yang berbeda agama menjadikan percakapan atau komunikasinya berdampak baik secara langsung maupun tidak langsung. Seperti misalnya yang dialami oleh informan Hadi Santoso (Tan Yoe Tjuan). Ia merasakan sendiri betapa hubungan antarpribadi dengan yang berlainan agama secara intensif dan akrab juga mampu menggoyahkan keimanan Hadi Santoso. Hubungan pertemanan dengan Rustiono yang sudah terlebih dahulu masuk Islam membuatnya dapat berpaling dari agama sebelumnya, yakni agama Khong $\mathrm{Hu}$ Chu.

b. Pengaruh Rutinitas Pekerjaan
Tingginya intensitas komunikasi dalam pergaulan dengan teman kerjanya yang beragama Islam dapat juga memberikan rasa penasaran dan juga pemahaman tentang agama Islam. Sementara rasa simpati terhadap agama Islam yang telah banyak dianut oleh kolega atau teman-temannya sangat menarik untuk diketahui secara mendalam. Wawancara yang dilakukan peneliti terhadap Soekotjo berikut memberikan gambaran bahwa kebiasaan rutin berteman juga membawa pengarauh atas proses konversi tersebut.

\section{Faktor Psikologis}

a. Faktor Intern

Yang dimaksud dengan faktor intern dalam konversi agama ini adalah adanya suatu kekuatan jiwa yang menguasai pusat kebiasaan seseorang sehingga pada dirinya muncul persepsi baru dalam bentuk suatu ide yang bersemi secara mantap. Konversi agama Islam bagi para etnis Cina di Ponorogo merupakan sebuah pergulatan batin yang panjang dan melelahkan. Bahkan sebagian informan menyatakan kesulitan dan keresahannya ketika harus menentukan keputusan untuk pindah agama ke Islam. Faktor psikologis dari dalam diri sendiri berupa persepsi terhadap Islam yang damai dan dapat menyelamatkan mereka dari dunia dan akhirat serta hidup yang mendapatkan ridlo dari Allah SWT adalah angan-angannya yang paling dominan untuk segera dapat terwujud.

b. Faktor Ekstern

Konversi agama dapat terjadi karena suatu krisis ataupun secara 
mendadak (tanpa suatu proses). Sebagian besar informan mengemukakan argumentasinya bahwa proses konversi agama dapat diklasifikasikan menjadi dua tahapan yaitu mereka yang berproses secara bertahap dan yang mendadak atau drastis. Bagi yang berproses secara bertahap seperti yang dialami oleh Hadi Hartono (Tan Yoe Tjuan) ketika mendengar suara adzan yang kemudian bergetar hatinya.

\section{B. Pola Perilaku Sosial Keagamaan}

Konversi agama memiliki dampak bagi pelakunya, baik dampak politik, sosial, agama, budaya, serta perilaku sosial keagamaan. Karena setiap pelaku konversi agama memiliki tujuan dan motif yang berbeda-beda, sehingga setelah melakukan konversi agama dan mengetahui aqidah dan syari'at serta berusaha untuk menjalankannya, maka dampaknya dapat dinilai dari pola perilaku sosial agamanya.

1. Pola Hubungan Etnis Cina dan Jawa

Secara kuantitas, jumlah masyarakat etnis Cina adalah minoritas dibanding dengan Jawa, akan tetapi mereka hidup bertetangga dengan rukun tanpa konflik yang berarti. Interaksi yang terjalin cenderung akrab meskipun mengalami konflik diantara dua etnis tersebut.

2. Pola Hubungan Konflik

Konflik yang terjadi akibat interelasi antar kepercayaan yang dianut sebelumnya dengan dogma baru dalam agama Islam dirasakan oleh hampir semua pelaku konversi agama. Upaya untuk membandingkan kejelasanan akan ajaran-ajaran seperti pola perilaku dalam konteks sosial kemasyarakatan, terlebih dalam hal ibadah merupakan salah satu faktor terjadinya konflik. Bagi agama sebelumnya (mayoritas dari agama Khong $\mathrm{Hu} \mathrm{Chu}$ ) memiliki pakem yang sangat longgar dan cenderung tidak mengikat. Sementara agama Islam memiliki pakem ibadah seperti sholat, zakat, puasa dan haji yang rigid dan mengikat. Seperti diakui oleh Hadi Wijaya bahwa sholat wajib lima waktu kalau tidak terbiasa dapat menjadi beban. Karena di saat ramai dan larisnya dagangan harus menyelenggarkan sholat Dhuhur. Tetapi diakui bahwa dari semua itu, hanya pakem Islam yang memiliki nilai-nilai transendental dan humanis. Karenanya, ibadah wajib harus dilakukan meskipun belum dapat dilakukan dengan sempurna.

3. Pola Hubungan Kompetitif

Pola hubungan yang kompetitif untuk mengemban dan menyiarkan Islam cukup dirasakan oleh pengurus PITI Ponorogo maupun tokoh masyarakat sekitar. Hal tersebut dapat ditengarai dengan berbagai kegiatan ritual keagamaan yang kadang-kadang mengindikasikan persaingan diantara kelompok keagamaan yang ada. Misalnya saja ketika akan melakukan persiapan peringatan Maulid Nabi Muhammad SAW. Di saat persoalan waktu, lokasi, kegiatan dan penceramah sudah diundang, pada waktu yang bersamaan dan tempat yang berdekatan juga diselenggarakan acara yang sama. Tentu yang demikian dalam pandangan lain agama mencerminkan adanya ketidakharmonisan diantara orang Islam, akan tetapi itulah yang terjadi sebagai bentuk pola hubungan yang 
menurut sebagian kelompok adalah kompetitif untuk memberikan yang terbaik dalam konteks syiar agama.

\section{Pola Interaksi Pelaku Konversi Agama}

1. Pola Interaksi Antara Cina Muslim dengan Cina Non Muslim

Konversi agama bagi etnis Cina tidak dilihat sebagai perubahan besar yang perlu mendapatkan perhatian serius. Siapapun dapat melakukan itu dengan berbagai alasan, sehingga konversi agama merupakan urusan pribadi-pribadi pelakunya. Karenanya, tidak ada sikap yang perlu dirubah dari baik menjadi jelek atau sebaliknya, semuanya sama saja.

Etnis Cina itu tidak mengurusi agama karena konversi agama merupakan perilaku yang sifatnya privacy. Pandangan bahwa sikap dan perilaku terhadap Cina Muslim dan Cina Non Muslim dalam sudut pandang interaksi sosial yang tidak mengalami perubahan tersebut lebih disebabkan oleh sikap yang cenderung lebih mengutamakan bisnis.

2. Pola Interaksi Cina Muslim dengan Jawa Muslim

Persepsi masyarakat Jawa Muslim, terhadap etnis Cina yang melakukan konversi agama, sebagian ada yang mengatakan karena ingin mencari keselamatan sosial politik dari kelompok mayoritas, sebagian lain karena berupaya ingin membaur dengan etnis Jawa dan memperluas jaringan bisnis. Selain itu, dalam pandangan positif Jawa Muslim, beralihnya sebagian etnis Cina menjadi Muslim lebih disebabkan oleh keyakinan ada petunjuk Tuhan.

Interaksi sosial antara Cina muslim dengan Jawa muslim kurang harmonis disebabkan karena ada pemahaman yang berbeda tentang tindakan konversi agama antara kedua belah pihak.

Bagan 2

Pola Interaksi Yang Dihasilkan

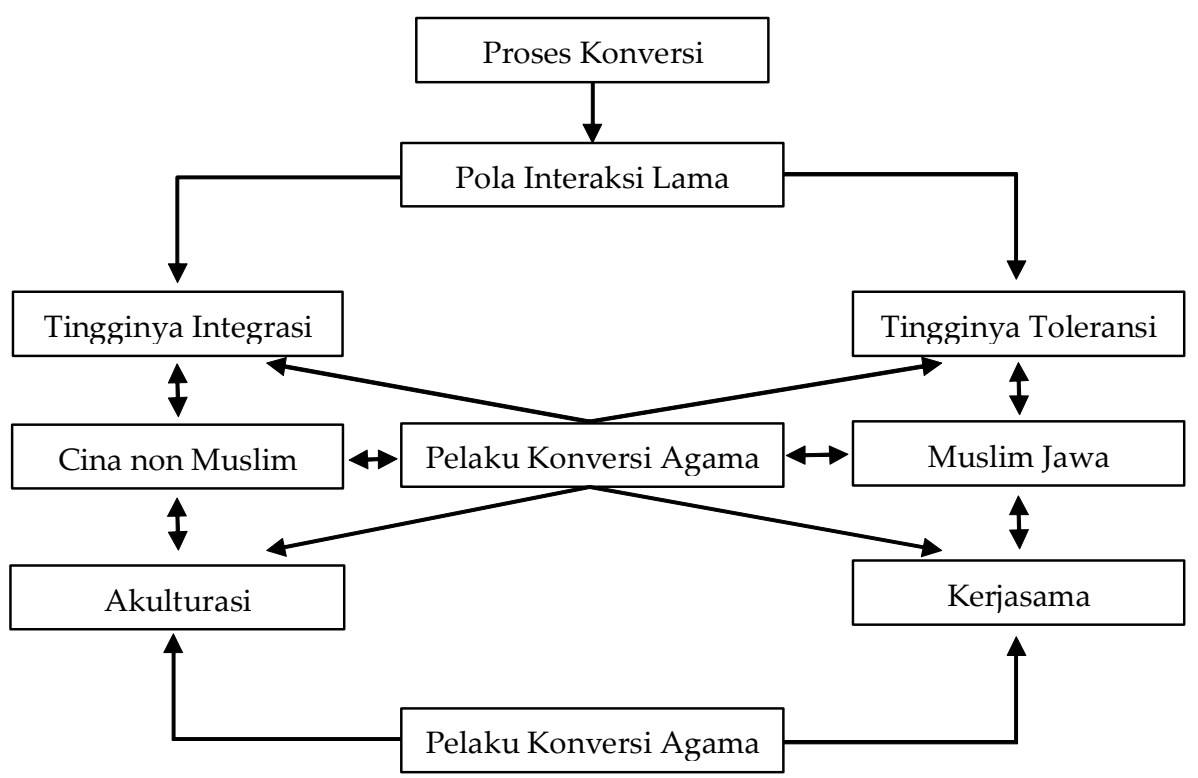

144 Dialog No. 68, Tahun XXXII, Nopember 2009 
V. Pembahasan

\section{A. Titik Singgung Dengan Teori INTERAKSIONISME SIMBOLIK}

Berdasarkan tinjauan teori interaksonisme simbolik, perilaku Cina Muslim untuk semakin dapat membaur dengan penuh, seperti etnis yang lainnya, ternyata tidak berhasil dengan maksimal. Lebih banyak pelaku yang sudah Muslim tetap mempertahankan komunitas dan loyalitas kepada kelompok sesama Cina (ekseklusif). Persepsi terhadap etnis Cina yang cenderung "miring" dan ekslusif dengan tindakan konversi agama dan perilaku sosial keagamaan belum dapat menjadikan bauran secara maksimal. Salah satu faktornya adalah sulitnya terjadi bauran budaya (akulturasi) antara budaya Jawa dengan Cina, dimana masing-masing budaya memiliki pola pandang sebagai suatu karya seni dari para leluhur yang harus dipertahankan tradisinya.

Pendekatan interaksionisme simbolik memberikan penekanan pada individu yang aktif dan kreatif daripada pendekatan-pendekatan teoritis lainnya. Pendekatan interaksionisme simbolik berkembang dari sebuah perhatian ke suatu arah dengan bahasa. Pendekatan interaksionisme simbolik menganggap bahwa segala sesuatu tersebut adalah virtual. Semua interaksi antarindividu manusia melibatkan suatu pertukaran simbol. Ketika etnis Cina melakukan interaksi dengan masyarakat Jawa, secara konstan mereka mencari "petunjuk" mengenai tipe perilaku apakah yang cocok dalam konteks itu dan mengenai bagaimana menginterprestasikan apa yang dimaksudkan oleh orang lain. Interaksionisme simbolik mengarahkan perhatian kita pada interaksi antarindividu, dan bagaimana hal itu bisa dipergunakan untuk mengerti apa yang orang lain katakan dan lakukan kepada kita sebagai individu. Sebaliknya, dalam penelitian ini perilaku yang ditunjukkan pelaku konversi agama dengan berusaha membaur dan berkumpul sesama Muslim yang lainnya (Jawa) tidak mendapatkan apresiasi yang diharapkan. Justru dengan sesama etnis Cina, baik Muslim atau non Muslim justru terjalin hubungan yang harmonis sebagaimana pola kerja sama yang terjadi sebelum tindakan konversi agama dilakukan.

Kembali merujuk pada teori interaksionisme simbolik dimana masyarakat tersusun dari individuindividu yang berinteraksi dan berkreasi, masyarakat yang menangkap, menginterprestasi, berpikir dan mencipta. Individu bukanlah sekelompok sifat, namun merupakan seorang aktor yang dinamis dan berubah, yang selalu berada dalam proses menjadi dan tidak pernah selesai terbentuk sepenuhnya. Masyarakat bukanlah sesuatu yang statis "di luar sana" yang selalu mempengaruhi dan membentuk dari kita, namun pada hakekatnya merupakan sebuah proses interaksi. Individu bukan hanya memiliki pikiran (mind), namun juga diri (self) yang bukan sebuah entitas psikologis, namun sebuah aspek dari proses sosial yang muncul dalam proses pengalaman dan aktifitas sosial. Selain itu keseluruhan proses interaksi tersebut bersifat simbolik, dimana makna-makna tersebut dibentuk oleh akal budi manusia.

\section{B. Titik Singgung Dengan Teori FENOMENOLOGI}

Pada teori ini memiliki asusmsi 
bahwa tindakan manusia menjadi suatu hubungan sosial bila manusia memberikan arti atau makna tertentu terhadap tindakannya itu dan manusia lain memahami pula tindakannya itu sebagai suatu yang penuh arti.

Dalam nilai tindakan konversi agama yang lain, hubungan sosial antara etnis Cina sebagai pelaku konversi dengan Cina non Islam tidak mengalami pergeseran pola hubungan. Dalam hal ini, melakukan atau tidak melakukan konversi agama tidak memiliki pengaruh signifikan terhadap jalinan interaksi sesama etnis. Bagi pelaku konversi agama awal tindakannya dimaknai akan dapat mengganggu pola hubungan diantaranya, namun hal tersebut pada mulanya secara langsung berdampak pada pola interaksi. Akan tetapi lama kelamaan mengalami pergeseran pada kondisi semula. Sehingga tidak mengalami gangguan pada pola hubungan sosial.

Dengan melihat fenomena dan teori fenomenologi-nya Schutz dimana dimensi pemisahan dari kesadaran umum kepada kesadaran khusus kelompok sosial yang saling berinteraksi sehingga perhatiannya hanya pada satu bentuk dari subjektifitas yang disebut antar subjektifitas, maka faktor saling memahami satu sama lain baik antarindividu maupun antar kelompok dalam konteks konversi agama bagi etnis Cina, memiliki titik singgung teori yang bertolak belakang dari temuan data yang diperoleh.

Pola berikut adalah skema temuan dari proses konversi agama dan menunjukan titik singgung teori yang digunakan.

\section{Skema Temuan Hasil Penelitian dan Titik Singgung dengan Teori Yang Digunakan}

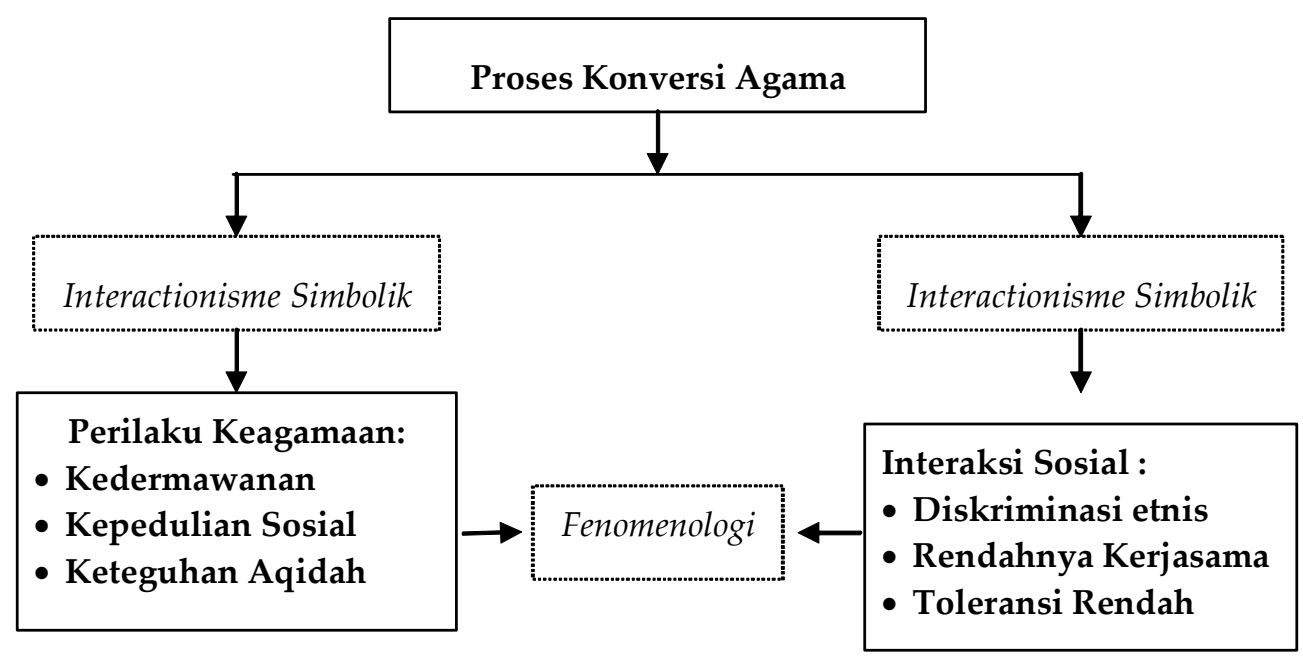

146 Dialog No. 68, Tahun XXXII, Nopember 2009 


\section{Temuan Penelitian dan \\ Proposisi \\ - Proposisi 1 :}

"Konversi agama menghasilkan pola perilaku sosial keagamaan yang mengarah pada kedermawanan, tingginya kepedulian sosial, dan keteguhan aqidah. Tetapi kelas sosial etnis yang ekseklusif tidak berubah menuju inklusif, sehingga keterikatan etnis lebih kuat dari pada keterikatan agama, kemudian berdampak. pada kecurigaan dan diskriminasi baik dari masyarakat Jawa muslim maupun Pemerintah setempat".

\section{- Proposisi 2 :}

"Orientasi kemasyarakatan dan keagamaan menghasilkan pola interaksi yang kurang harmonis antara pelaku konversi agama dengan masyarakat Jawa muslim, sehingga proses asimilasi dan kerjasama tidak dapat berlangsung dengan baik, sementara pola interaksi antara pelaku konversi agama dengan Cina non Muslim masih harmonis".

\section{Vi . Penutup}

\section{A. Kesimpulan}

1. Tindakan konversi agama etnis Cina di Ponorogo menghasilkan perilaku sosial keagamaan yang lebih mantab dan jelas dalam aspek aqidah dan syari'ah. Sehingga melahirkan perilaku sosial dalam bentuk meningkatkan kedermawanan dan juga semakin tingginya kepedulian sosial. Hal tersebut sebagai bentuk implikasi dari nilai-nilai agama baru (Islam) bagi pelaku konversi agama.

2. Konversi agama etnis Cina tidak paralel dengan perubahan persepsi masyarakat sekitarnya (Jawa muslim) yang lebih menilai ekseklusif dan materialistik. Sehingga interaksi sosial yang terjadi antara sebelum konversi agama dan sesudahnya tidak mengalami pergeseran atau peningkatan yang signifikan, baik kepada Jawa muslim maupun kepada sesama etnis Cina non muslim.

3. Perilaku sosial keagamaan sebagai hasil dari berjalannya sistem nilai dari agama baru (Islam) bagi pelaku konversi agama di satu sisi menghasilkan perubahan perilaku yang sesuai dengan ajaran Islam, Akan tetapi disisi lain karena tidak bergesernya persepsi negatif masyarakat (muslim Jawa) tentang ekseklusifitas etnis, maka perilaku diskriminatif yang dilakukan oleh masyarakat maupun pemerintah seringkali dirasakan oleh perlaku konversi agama.

\section{B. SARAN - SARAN}

1. Hendaknya akulturasi antara Cina dan Jawa dengan mengusung nilainilai Islam mampu memperluas ruang gerak bagi pelaku konversi agama dengan non Islam pada umumnya. Dengan masih menonjolkan sektarianisme kelompok, maka pembauran akan sulit dilakukan dengan maksimal.

2. Masyarakat Jawa hendaknya tidak berlebihan dalam mempersepsi dan meberlakukan Cina muslim. Sehingga tidak ada lagi diskriminasi dan terjalinnya hubungan kerja sama dapat semakin ditingkatkan antara kedua belah pihak.

3. Pemerintah, PITI, organisasi keagamaan Islam lainnya seperti NU, Muhammadiyah perlu 
meningkatkan silaturahmi untuk mengurangi persepsi negatif dan sekaligus meningkatkan kerjasama antar sesama umat Islam dalam mengemban amanat Allah sebagi Kholifah dimuka bumi ini.

\section{DAFTAR PUSTAKA}

Aduito, Joseph, 1978, Communicology an Introduction to the Study of Communication, New York: Row Publishers.

Al-Ghazali, t.t.. Penyelamat dari Kesesatan, Surabaya: Pustaka Pelajar.

Aplikasia, Jurnal, "Jurnal Aplikasi Ilmuilmu Agama" Vol. 1, No. 1, Desember 2000, Yogyakarta.

Blumer, Herbert, 1989. Simbolic Interactionism, London: University of California Press.

Coppel, C.A., 1983, Indonesia Chinese in Crisis, Oxford: Oxford University Press.

Geertz, Clifford, 1997. The Interpretation of Culture, New York: Basic book, Inc.

Gidden, Anthony \& Jonathan H. Turner, 1988. Sosial Theory Today, California: Oxford University Press.

Gordon, Scott, 1991. The History and Philosophy of Sosial Sciene, Manila: Routledge, Chapman and Hall, Inc.

Kose, Ali, 1996, Convertion to Islam, London: Kegan Paul International.

Mackey, J.A.C, 1991. The Chinese in Indonesia, Honolulu: The University of Hawai.
Mely G. Tan, 1991. The Sosial and Cultural Dimensios of The Role of Ethnic Chinese in Indonesia Society, in Indonesia, Cornell Southeast Asia Program.

Moleong, Lexy J., 1998. Metodologi Penelitian Kualitatif, Bandung: Remaja Rosdakarya.

Musianto, Lukas, Sugeng, 1998. Interaksi Etnik Cina dan Pribumi di Surabaya, Disertasi UNAIR.

Poloma, Margaret, 2000. Sosiologi Kontemporer, Yogyakarta: Raja Grafindo Persada.

Rahman, T., Abdur, 1989, New Convert to Islam, dalam IqbalA. Ansari, The Muslim Situation in India, Dhaha: Institute of Objective Studies.

Ritzer, George, 1992, Sosiologi Ilmu Pengetahuan Berparadigma Ganda. Terj., Alimandan. Jakarta, Raja Grafindo.

Tan, Mely G.. 1991. "The Sosial and Cultural Dimension of Ethnic Chenese in Indonesian society", Jurnal Indonesia, Cornell Southeast Asia Program, Ithaca.

Weber, Max, 2002. sosiologi Agama, Yogyakarta: Ircisod.

Zein, Abdul Baqir, 2000. Etnis Cina dalam Potret Pembauran di Indonesia, Jakarta: Presentasi Insan Indonesia. 